PENELITIAN

\title{
Pengaruh Ketorolak dan Parekoksib Terhadap Gambaran Histopatologi Gaster Tikus Wistar
}

\section{The Effect Of Ketorolac and Parecoxib On Wistar Rats Gaster Histopathology}

Retno Tri Siswanti $\bigotimes^{*}$, Danu Soesilowati**, Uripno Budiono**, Devia Eka Listiana***

* RS Islam Jakarta Utara

** Bagian Anestesi dan Terapi Intensif Fakultas Kedokteran Universitas Diponegoro/ RSUP Dr. Kariadi Semarang.

*** Bagian Patologi Anatomi Fakultas Kedokteran Universitas Diponegoro/ RSUP Dr. Kariadi Semarang.

$\triangle$ Korespondensi/Correspondence: retnotrisiswanti@yahoomail.com

\section{ABSTRACT}

Background: Non Steroid Anti Inflammation Drugs (NSAID) are used as post operative analgetic. NSAID inhibit prostaglandin (PG) synthesis, an inflammatory mediator, resulting minimal manifestation of inflammatory markers. But the PG, especially PGE2, actually a substance that protects the digestive system mucous channel. PG synthesis barriers will reduce the resilience of mucosa, and the effect will be mild to severe form for acutemucosal lesion, these called gastropati NSAID, which is associated with NSAID therapy.

Objective: To compare the gaster histopathology on wistar rats that were given ketorolac intramuscular to parecoxib intramuscular.

Methods: This is a laboratory experimental randomized post test control group design in 21 male wistar rat which are divided into 3 groups: a control group (K) wistar rats given $2 \mathrm{~cm}$ incision wounds and not given any of the drugs. The P1 group was given 2 $\mathrm{cm}$ incision wounds and an injection of human dose equivalent intramuscular ketorolac $30 \mathrm{mg}$ every 8 hours, the $P 2$ group was given $2 \mathrm{~cm}$ incision wounds and the human dose equivalent of parecoxib injection $40 \mathrm{mg}$ every 12 hours. On the 5th day, termination was conducted, and onthe 6th day we performed paraffin block manufacture.

Results: Ketorolac $0.54 \mathrm{mg} / 8$ hours which was given for 5 days gave significant $(p<0,01)$ severe damage to gastric mucosal integrity wistar rats compared to parecoxib $0.72 \mathrm{mg} / 12$ hours for 5 days.

Conclusion: parecoxib given less gastric mucous damage compared to ketorolac

Keywords: Ketorolac, Parecoxib, gastric mucosal integrity

\section{ABSTRAK}


Latar Belakang : Obat antiinflamasi nonsteroid (OAINS) digunakan sebagai analgetik paska operasi. Berbagai jenis OAINS dapat menghambat sintesis prostaglandin (PG) yang merupakan mediator inflamasi dan mengakibatkan berkurangnya tanda inflamasi.Akan tetapi PG khususnya PGI sebenarnya merupakan zat yang bersifat protektor untuk mukosa saluran cerna atas. Hambatan sintesis PG akan mengurangi ketahanan mukosa, dengan efek berupa lesi akut mukosa gaster bentuk ringan sampai berat. Gastropati OAINS adalah lesi mukosa gaster yang berhubungan dengan terapi OAINS.

Tujuan : Membandingkan gambaran histopatologi gaster antara tikus wistar yang diberikan ketorolak intramuskular dan parekoksib intramuskular.

Metode : Dilakukan penelitian eksperimental laboratorik menggunakan randomized post test control group design pada 21 ekor tikus wistar jantan yang terbagi dalam 3 kelompok yaitu kelompok kontrol (K) tikus wistar yang diberikan luka insisi sepanjang $2 \mathrm{~cm}$ dan tidak diberikan injeksi ketorolak maupun parekoksib, Kelompok perlakuan 1 (P1) tikus wistar yang diberikan luka insisi sepanjang $2 \mathrm{~cm}$ dan diberikan injeksi ketorolak intramuskuler setara dosis manusia 30 mg tiap 8 jam, kelompok perlakuan 2 (P2) tikus wistar yang diberikan luka insisi sepanjang $2 \mathrm{~cm}$ dan diberikan injeksi parekoksib setara dosis manusia $40 \mathrm{mg}$ tiap 12 jam. Pada hari ke 5 dilakukan terminasi dan pada hari ke 6 dilakukan pembuatan blok parafin.

Hasil : Ketorolak 0,54 mg/8 jam selama 5 hari mempengaruhi integritas mukosa lambung tikus wistar lebih buruk dibandingkan dengan parekoksib 0,72 mg /12 jam selama 5 hari $(p<0,001)$

Kesimpulan :Parecoxib kurang menimbulkan kerusakan mukosa lambung dibandingkan ketorolak.

Kata Kunci : Ketorolak, Parekoksib, integritas mukosa lambung

\section{PENDAHULUAN}

Obat anti inflamasi non steroid (OAINS) adalah analgetik yang biasa dipakai untuk mengatasi nyeri pasca operasi. Obat tersebut bisa dipakai secara tunggal untuk mengatasi nyeri ringan sampai sedang, atau dipakai bersama narkotik untuk mengatasi nyeri berat. Pemakaian narkotik bersama OAINS bertujuan untuk mengurangi dosis narkotik, sehingga efek samping yang ditimbulkan oleh narkotik bisa dikurangi. ${ }^{1}$

OAINS berkerja menghambat enzim cyclooksigenase (COX) pada proses esterifikasi asam arahkidonat menjadi prostaglandin. Enzim cyclooksigenase ada 2 bentuk yaitu cyclooksigenase 1 (COX-1) dan 
cyclooksigenase 2 (COX-2). COX-1 menyebabkan terbentuknya PGE 1 yaitu prostaglandin yang berfungsi melindungi mukosa gaster, mengurangi agregasi platelet dan mendukung fungsi ginjal. Sedangkan COX-2 menyebabkan terbentuknya PGE 2 yaitu prostagklandin yang merangsang terjadinya inflamasi, nyeri, dan demam. ${ }^{1,2,3,4}$

Ketorolak dan parecoxib adalah OAINS yang biasa digunakan untuk mengurangi nyeri pasca operasi. Sebagai OAINS non selektif ketorolak menyebabkan hambatan pada COX-1 dan COX-2 dengan hambatan pada COX-2 yang lemah. ${ }^{5,6,7}$ Karena itu pada pemberian ketorolak rasa nyeri akan berkurang karena hambatan pada COX2, tetapi perlindungan pada mukosa gaster akan berkurang karena terhambatnya COX-1. Parecoxib termasuk OAINS selektif yang hanya menghambat COX-2, karena itu akibat pemberian parecoxib rasa nyeri akan berkurang, tetapi perlindungan pada mukosa gaster tetap berjalan karena tidak terjadi hambatan pada COX-1. ${ }^{8}$

Terhambatnya perlindungan pada mukosa gaster akibat pemberian OAINS dapat menyebabkan lesi akut pada mukosa gaster yang disebut gastropati OAINS, jika tidak tertangani dengan baik dapat timbul komplikasi antara lain perdarahan gastrointestinal, hematemesis, melena, perforasi, striktur, syok hipovolemik dan kematian. ${ }^{9} 10-60 \%$ pengguna OAINS mengalami dispepsia, sehingga 5-15\% pasien artritis yang menggunakan OAINS dihentikan penggunaannya. 10$30 \%$ pasien ulkus peptikum adalah pasien yang menggunakan OAINS. ${ }^{10}$

Karena itu, sebagai golongan OAINS, pengaruh ketorolak dan parecoxib terhadap gaster khususnya gambaran histopatologinya masih menarik untuk diteliti. Penelitian pengaruh OAINS pada gaster manusia telah dilakukan menggunakan endoskopi antara lain membandingkan parecoxib, ketorolak dan placebo; parecoxib, naproxen, ketorolak dan placebo; rofecoxib, ibuprofen dan placebo; selecoxib dan OAINS lain. ${ }^{11-14}$ Sedang penelitian pada binatang percobaan antara lain membandingkan secara makroskopik kerusakan dan permeabilitas intestinum tikus yang diberi rofecoxib dan indomethacin COX2 dan penyembuhan ulkus peptikum. ${ }^{15,16}$ Penelitian pada binatang percobaan secara makroskopik juga telah dilakukan di Indonesia membandingkan lambung pada tikus putih yang diberi aspirin dan placebo. ${ }^{17}$

Penelitian ini berbeda dengan penelitian yang telah dilakukan di atas, karena penelitian ini memeriksa gambaran histopatologi gaster akibat pemberian ketorolak dan parecoxib. Penelitian ini menggunakan lambung tikus wistar sebagai sampel karenaterdapat hambatan untuk mengambil sampel pada manusia.

\section{METODE}


Penelitian ini merupakan penelitian eksperimental murni dengan pendekatan post test only group design menggunakan tikus wistar jantan galur murni. Penelitian ini dilakukan di Laboratorium Biologi Fakultas Matematika dan Pengetahuan Alam Universitas Negeri Semarang. Pembuatan blok paraffin dan pemeriksaan histopatologi dilakukan di Laboratorium Patologi Anatomi Fakultas Kedokteran Universitas Diponegoro Semarang.

Menurut WHO besar sampel binatang percobaan minimal 5 ekor untuk setiap kelompok perlakuan. Pada penelitian ini sampel tiap perlakuan berjumlah 7 ekor, untuk mengatasi kemungkinan terjadi drop out sebesar 10\%.Karena dilakukan 3 macam perlakuan maka secara keseluruhan digunakan sebanyak 21 ekor.

Sebagai kriteria inklusi adalah tikus wistar jantan, umur antara 8-10 minggu, berat 230-300 gram, tampak aktif, dan dari pemeriksaan luar tidak ditemukan kelainan anatomis. Sebagai kriteria eksklusi adalah tikus selama adaptasi 7 hari tidak aktif, atau mati selama perlakuan.Sampel yang diteliti adalah mukosa gaster bagian corpus.

Semua tikus yang dijadikan sampel diaklimatisasi selama 7 hari dengan diletakkan dalam kandang khusus, tiap kandang diisi 1 ekor tikus, dengan ventilasi dan pencahayaan yang cukup dan sama. Kandang dibersihkan dengan tingkat kebersihan dan frekuensi yang sama. Makanan dan air minum diberikan secukupnya dengan makanan standar tikus berupa palet.

Semua tikus diberi anestesi ketamin, setelah teranestesi bulu punggung dicukur, punggung dibersihkan, didisinfeksi menggunakan betadin, kemudian dibuat luka insisi sepanjang $2 \mathrm{~cm}$ dengan kedalaman sampai subkutan. Luka irisan dibersihkan dan diolesi betadin, kemudian diberi $15 \mathrm{mg}$ penisiline oil.

Selanjutnya secara acak tikus dikelompokkan menjadi 3 kelompok perlakuan. Kelompok pertama (P1) adalah tikus yang diberikan ketorolac intramuskular tiap 8 jam setara dengan dosis pada manusia $30 \mathrm{mg}$ selama 5 hari.

Kelompok kedua (P2) adalah tikus yang diberikan parecoxib intramuskular tiap 12 jam yang setara dengan dosis pada manusia $40 \mathrm{mg}$ selama 5 hari.

Kelompok kontrol (K) adalah kelompok tikus yang tidak diberikan parecoxib ataupun ketorolac.

Penyetaraan dosis obat dengan manusia dilakukan dengan mengalihkan dosis pada manusia dengan faktor konstanta uji terapi pada hewan coba tikus wistar yang besarnya 0,018 sehingga dosis ketorolak adalah $0,018 \times 30 \mathrm{mg}$ yaitu $0,54 \mathrm{mg}$, sedangkan parecoxib adalah $0,018 \times 40 \mathrm{mg}$ yaitu $0,72 \mathrm{mg}$. 
Pada hari ke enam dilakukan terminasi terhadap semua tikus dengan cara dislokasi cervikal dan diambil gasternya dimasukkan kedalam botol yang berisi formalin $10 \%$, kemudian dibuat blok paraffin selanjutnya dibuat preparat dengan pewarnaan hemaktosilin eosin dan dibaca oleh ahli patologi anatomi yang tidak tahu pada perlakuan yang telah diberikan pada sampel.

Setiap preparat dibaca dalam 5 lapangan pandang dengan perbesaran 400x pada mukosa gaster bagian korpus. Sasaran yang dibaca adalah perubahan struktur histopatologi yang memperlihatkan permukaan fibrinopurulen dengan jaringan granulasi dibawahnya. Mukosa lambung menunjukkan gastritis kronis dengan adanya sel plasma didalam lamina propia dan metaplasia intestinal. Hasil pengamatan dimasukkan kedalam tabel dan dijumlahkan dengan skoring sesuai tabel 1 .

Data yang didapatkan diuji dengan uji Saphiro Wilk untuk melihat distribusi data, bila distribusi data normal dan varians datanya sama, diuji beda menggunakan statistik parametrik one way Anova, jika $\mathrm{p}<0,05$ dilanjutkan dengan uji Post Hoc. Bila distribusi data tidak normal atau varians tidak sama, maka dilakukan tranformasi data, jika hasil transformasi data tidak normal atau tidak sama, maka dilakukan uji beda menggunakan statistik non parametric Kruskal Wallis, jika didapat $\mathrm{p}<0,05$ dilanjutkan dengan uji Post Hoc (Mann Whitney Test).

\section{HASIL}

Pada penelitian ini tidak terjadi drop out sehingga didapat 7 ekor sampel untuk tiap kelompok. Kelompok P1 (ketorolak) didapatkan skor kerusakan integritas mukosa rata-rata $6,71 \pm 1,04$. Sedangkan Kelompok PII (parecoxib) didapatkan skor kerusakan integritas mucosa rata- rata $5,43 \pm 0,89$ dan dari kelompok K ( kontrol) didapat skor kerusakan integritas mukosa ratarata $5,28 \pm 0,86$.

Dari uji normalitas Shapiro Wilk maupun uji homogenitas (levene statistic) didapat nilai $\mathrm{p}>$ 0,05 maka disimpulkan bahwa data homogen dan berdistribusi normal. Sehingga dapat diteruskan dengan one way Annova

Nilai p antara kelompok kontrol (K) dan kelompok ketorolak (P1) lebih kecil dari 0,001 maka perbedaan antara kelompok kontrol dan ketorolak bermakna, sementara nilai $\mathrm{p}$ antara kelompok kontrol dan parecoxib adalah 0,516, karena lebih besar dari 0,05 maka perbedaan antara kelompok kontrol dan kelompok parecoxib tidak bermakna. Sedangkan nilai antara kelompok ketorolac dan parecoxib adalah 0,008, karena lebih kecil dari 0,05 maka perbedaan antara kelompok parecoxib dan kelompok ketorolak bermakna.

PEMBAHASAN 
Tabel 1. Skoring integritas mukosa gaster

\begin{tabular}{ll}
\hline Definisi & Skor \\
\hline Mukosa Normal & 1 \\
\hline Erosi hingga pada epitel permukaan & 2 \\
\hline Erosi sampai kedalaman 1/3 bagian atas kelenjar & 3 \\
\hline Erosi sampai kedalaman 1/3 bagian tengah kelenjar & 4 \\
\hline Erosi sampai kedalaman 1/3 bagian bawah kelenjar & 5 \\
\hline Erosi mengenai muskularis mukosa & 6 \\
\hline
\end{tabular}

Tabel 2. Skor kerusakan integritas mukosa gaster

\begin{tabular}{|c|c|c|c|c|c|c|c|c|c|c|c|c|c|c|c|c|c|c|}
\hline \multirow{5}{*}{ Tikus } & \multicolumn{6}{|c|}{$\begin{array}{c}\text { Kelompok PI } \\
\text { (Ketorolak ) }\end{array}$} & \multicolumn{6}{|c|}{$\begin{array}{c}\text { Kelompok PII } \\
\text { ( Parecoxib) }\end{array}$} & \multicolumn{6}{|c|}{$\begin{array}{c}\begin{array}{c}\text { Kelompok P III } \\
(\text { Kontrol })\end{array} \\
\end{array}$} \\
\hline & $\bar{L}$ & $\mathrm{~L}$ & $\mathrm{~L}$ & $\mathrm{~L}$ & $\overline{\mathrm{L}}$ & & $\mathrm{L}$ & $\bar{L}$ & $\bar{L}$ & $\bar{L}$ & $\mathrm{~L}$ & & $\bar{L}$ & $\bar{L}$ & $\mathrm{~L}$ & $\mathrm{~L}$ & $\bar{L}$ & \\
\hline & $P$ & $\mathrm{P}$ & $\mathrm{P}$ & $\mathrm{P}$ & $\mathrm{P}$ & & $\mathrm{P}$ & $\mathrm{P}$ & $\mathrm{P}$ & $\mathrm{P}$ & $\mathrm{P}$ & $\Gamma$ & $\mathrm{P}$ & $\mathrm{P}$ & $\mathrm{P}$ & $\mathrm{P}$ & $P$ & \\
\hline & 1 & II & II & I & V & 2 & I & II & II & I & V & 2 & I & II & II & I & V & 2 \\
\hline & & & I & $\mathrm{V}$ & & & & & I & $\mathrm{V}$ & & & & & & $\mathrm{V}$ & & \\
\hline I & 1 & 1 & 1 & 1 & 2 & 6 & 1 & 1 & 1 & 1 & 1 & 5 & 1 & 1 & 1 & 1 & 1 & 5 \\
\hline$\overline{\mathrm{II}}$ & 1 & 2 & 2 & 3 & 1 & 9 & 1 & 1 & 1 & 1 & 1 & 6 & 1 & 1 & 1 & 1 & 1 & $\overline{5}$ \\
\hline III & $\overline{1}$ & 1 & 1 & $\overline{1}$ & 1 & 5 & 1 & 1 & 1 & 1 & 1 & 5 & 1 & 1 & 2 & 1 & 1 & 6 \\
\hline IV & 1 & 2 & 1 & 2 & 1 & 7 & 1 & 1 & 1 & 1 & 1 & 6 & 1 & 1 & 1 & 1 & 1 & 5 \\
\hline$\overline{\mathrm{V}}$ & 1 & 1 & 2 & 1 & 1 & 6 & 1 & 1 & 1 & 1 & 1 & 5 & 1 & 1 & 1 & 1 & 1 & 5 \\
\hline VI & 1 & 2 & 2 & 3 & 1 & 9 & 1 & 1 & 2 & 1 & 1 & 6 & 1 & 2 & 1 & 1 & 1 & 6 \\
\hline VII & 1 & 1 & 3 & 1 & 1 & 5 & 1 & 1 & 1 & 1 & 1 & 5 & 1 & 1 & 1 & 1 & 1 & 5 \\
\hline & & & & & $\Sigma$ & 47 & & & & & $\Sigma$ & 38 & & & & & $\Sigma$ & 37 \\
\hline & & & & & & 6,7 & & & & & & 5,4 & & & & & & 5,2 \\
\hline & & & & & & 1 & & & & & & 3 & & & & & & 8 \\
\hline & & & & & $\mathrm{S}$ & $\overline{1,0}$ & & & & & $\mathrm{~S}$ & 0,8 & & & & & $\mathrm{~S}$ & $\overline{0,8}$ \\
\hline & & & & & D & 4 & & & & & D & 9 & & & & & D & 6 \\
\hline
\end{tabular}

Suatu postulat telah diajukan bahwa hambatan biosintesa COX-1 yang ditimbulkan oleh OAINS dalam lambung merupakan faktor kunci terbentuknya erosi pada gaster. ${ }^{18}$ Hal ini didukung dari hasil penelitian dimana OAINS selektif penghambat COX-2 menunjukkan angka erosi gaster yang lebih rendah dibanding OAINS non selektif. ${ }^{19,20}$ Selain itu terjadi nya perdarahan pada ulkus peptikum atau komplikasi gastrointestinal merupakan akibat dari penggunaan OAINS non selektif. ${ }^{21,22}$

Tetapi hipotesa tersebut tidak sesuai dengan hasil penelitian pada tikus dengan gen pembentuk COX-1 yang telah dirusak sehingga sintesa PGE1 sangat 
berkurang. Dari penelitian tersebut ternyata tidak terjadi kerusakan pada gaster menurut hipotesa tersebut seharusnya terjadi kerusakan pada gaster. Tetapi bila tikus-tikus tersebut diberikan indometasin, suatu penghambat COX-1 dan COX-2, tikustikus tersebut mengalami erosi gaster. ${ }^{23}$ Penelitian Smith, dkk menunjukkan bahwa tikus yang mendapat penghambat COX-1 selektif (SC 560) sehingga PGE1 pada gaster sangat rendah, juga tidak didapatkan pengaruh pada integritas mukosagaster. ${ }^{24}$ Karena itu timbul dugaan ada factor lain yang bekerja bersama-sama dengan penghambat COX agar terjadi kerusakan mukosa gaster.

Dalam keadaan normal, untuk mempertahankan diri resistensi mukosa gaster akan meningkat bila mendapat topical iritan misalnya etanol absolut. Tetapi pada penelitian Gretzer, dkk peningkatan resistensi mukosa lambung tidak terjadi bila sebelum diberikan etanol absolut sebagai topikal iritan, diberikan lebih dahulu inhibitor COX-2 selektif, menimbulkan dugaan bahwa COX-2 mempunyai peranan dalam pertahanan mukosa lambung. ${ }^{25}$ Hal ini didukung oleh penelitian-penelitian lain. $^{26-28}$

Pemakaian OAINS non selektif
untuk mengurangi nyeri akan
menghambat baik COX-1 maupun
COX-2, sering menimbulkan erosi dan
ulserasi gaster, mengarahkan dugaan
bahwa kerusakan pada gaster
diakibatkan oleh hambatan pada sintesa

kedua enzim tersebut. Hal ini terbukti dari penelitian Wallace, dkk dimana kerusakan lambung tidak terjadi pada tikus yang hanya diberi penghambat sintesa COX-1 atau hanya diberi penghambat COX-2 tetapi kerusakan lambung terjadi pada kelompok tikus yang diberi penghambat COX-1 dan penghambat COX-2. ${ }^{29}$

Hasil penelitian ini menunjukkan skor kerusakan integritas mukosa lambung tertinggi terjadi pada kelompok tikus yang mendapat ketorolak, dan skor kerusakan integritas mukosa lambung ini berbeda bermakna bila dibandingkan dengan skor kerusakan integritas mukosa lambung baik dengan kelompok tikus yang mendapat parecoxib maupun kelompok kontrol.

Hal ini dimungkinkan karena ketorolak termasuk OAINS non selektif yang menghambat baik COX-1 dan COX-2 sesuai dengan penelitian pada binatang percobaan sebelumnya (29). Keadaan ini juga sesuai dengan yang terjadi pada manusia dimana efek samping kerusakan pada gaster dialami oleh pengguna OAINS non selektif. $10,21,22$

Pada penelitian ini skor kerusakan integritas mukosa gaster pada kelompok parecoxib lebih rendah dibanding dengan kelompok ketorolak, hal ini dimungkinkan karena ketorolak termasuk OAINS yang menghambat baik COX-1 maupun COX-2 sedang parecoxib hanya menghambat COX-2 dan sesuai dengan yang terjadi baik 
pada binatang percobaan ${ }^{15,19,20}$ maupun pada manusia. ${ }^{11,12,13}$

\section{SIMPULAN}

Dari pemeriksaan histopatologi skor kerusakan integritas mukosa gaster pada kelompok ketorolak lebih tinggi dan bermakna dibandingkan dengan kelompok parecoxib maupun kelompok kontrol. Skor kerusakan integritas mukosa gaster kelompok parecoxib lebih tinggi dibanding kelompok kontrol tetapi perbedaan ini tidak bermakna.

Jadi disimpulkan bahwa parecoxib kurang menimbulkan kerusakan mukosa lambung dibandingkan ketorolak.

\section{DAFTAR PUSTAKA}

1. Mccrory CR, Lindahl SGE. Cyclooxygenase Inhibition for post operative analgesia. Anesth analg 2002; 95:169-76

2. Gajraj NM. Cyclooxygenase 2 inhibitors. Anesth analg 2003; 96: 11720-38

3. Vane Jr, Booting RM. Mechanism of action of anti-inflammatory drugs. Scan J Rheumatol 1996; 25 suppl 102: 9-21

4. Vane J, Bakhle Y, Botting R. Cyclooxygenase 1 and 2. Annu Rev Pharmacol Toxicol 1998;38:97-120.

5. Laneuville O, Breuer DK, De Witt DL,et al. Differential inhibition of human prostaglandin endoperoxide $\mathrm{H}$ synthases1 and -2 by nonsteroidal anti inflammatory drugs. J Pharmacol Exp Ther 1994; 271: 927-34

6. Carabaza A, Cabre F, Rottlan E, et al. Stereoselective inhibitor of inducible cyclooxygenase by chiral nonsteroidal anti-inflammatory drugs. J clin Pharmacol 1996; 36: 36: 505-12

7. Smith WL, Dewitt DL. Prostaglandin endoperoxide $\mathrm{H}$ synthases- 1 and -2 . Adv Immunol 1996; 62: 167-215

8. Cheer SM, Goa KL. Parecoxib (Parecoxib
Sodium). DRUGS 2001; 61:1133-41

9. Hawkey CJ. Nonsteroidal antiinflammatory drugs gastropathy. Gastroenterology 2000; 119:5221-35

10. Lazzaroni M, Porro GB. Gastrointestinal side effects of traditional non steroid anti inflammatory drugs and new formulations. AP\&T 2004; 20:48-58.

11. Harris SI, Stolz RR, Le Comte D, Hubbard RC. Parecoxib sodium demonstrates gastrointestinal safety comparable to placebo in healthy subjects. J Clin Gastroenterol 2004; 38: 575-80.

12. Harris SI, Kuss M, Hubbard RC, Goldstein JL. Upper gastrointestinal safety evaluation of parecoxib sodium, a new parenteral cyclooxygenase 2 spesific inhibitor compared with ketorolac, naproxen and placebo. Clin Ther 2001; 23: 1422-8.

13. Laine L, Harper S, Simon $\mathrm{T}$, Bath $\mathrm{R}$, Johanson J, Schwartz $\mathrm{H}$ et al. A randomized trial comparing the effect of rofecoxib, a cyclooxygenase- 2 spesific inhibitor with that of ibuprofen on the gastroduodenal mucosa of patients with osteoarthritis. Gastroenterology 1999; 117:776-83.

14. Deeks JJ, Smith LA, Bradley MD. Efficacy, tolerability and upper gastrointestinal safety of celecoxib for treatment of osteoarthritis and rheumatoid arthritis: systematic review of randomized controlled trials. BMJ 2002; 325: 619.

15. Leite AZ, Sipahi AM, Damiao AO, Garcez AT, Buchpiquel CA, Lopasso FP et al. Effect of selective non steroidal antiinflammatory inhibitor cyclooxygenase 2 on the small bowel of rats. BRAZ J MED BIOL RES 2004; 37: 333-6

16. Shigeta J, Takahashi S, Okabe S. Role of cyclooxygenase-2 in the healing of gastric ulcers in rats.

17. Manan C, Pridsoeryanto BP, Daldiyono Estuningsih S, Rahminiwati M. Dyspepsia in nonsteroidal antiinflamatory drug gastropathy. The Indonesia Journal of Gastroenterology Hepatology and Digestive Endoscopy. 2011; 12: 100-103.

18. Warner TD, Giuliano F, VojnovicI, et al Nonsteroid drug selectivities for cyclooxygenase-1 rather than cyclooxygenase-2 are associated with human gastrointestinal toxicity: a full in vitro analysis. Proc Natl Acad Sci USA 1999; 96: 7563-8

19. Masferrer JL, Zweifel BS, Manning PT, 
Hauser SD, Leahy KM, Smith WG, Isakson PC, Seibert K. Selective inhibition of inducible cyclooxygenase 2 in vivo is anti-inflammatory and non ulcerogenic. Proc Natl Acad Sci U S A 1994; 91:32283232.

20. Chan Cc, Boyce S, Brideau C, et al. Pharmacology of a selective cyclooxygenase-2 inhibitor, L-745, 337: a novel nonsteroidal anti-inflammatory agent with an ulcerogenic sparring effect in rat and nonhuman primate stomach. $\mathrm{J}$ Pharmacol Exp Ther 1995; 274:1531-1537

21. Langman M, Weil J, Wainwright $P$, et al. Risk of bleeding peptic ulcer associated with individual nonsteroidal antiinflammatory drugs. Lancet 1994; 343:1075-8.

22. Gabriel S, Jaakkimainen L, Bombardier C.Risk for serious gastrointestinal complications related to the use of nonsteroidal anti-inflammatory drugs: a meta analysis. Ann Intern Med 1991; 115:787-96

23. Langenbach R, Morham SG, Tiano HF, Loffin CD, Ghanayem BI Chulada et al. Prostaglandin synthase 1 gene disruption in mice reduces arachidonic acid-induced inflammation and indomethacin-induced gastric ulceration. Cell 1995; 83:483-492

24. Smith CJ, Zhang Y, Kobold CM, Muhammad J, Zweifel BS, Shaffer A, Thalley JJ, Masferrer JL, Seibert K,
Isakson PC. Pharmacological analysis of cyclooxygenase-1 in inflammation. Proc Natl Acad Sci U S A 1998; 95:1331313318.

25. Gretzer B, Ehrlich K, Maricic N, Lambrecht N, Respondek M, Peskar BM. Selective cyclooxygenase- 2 inhibitors and their influenced on the protective effect of a mild irritant in the rat stomach. $\mathrm{Br} \mathrm{J}$ Pharmacol 1998; 123:927-935.

26. Mizuno H, Sakamoto C, Matsuda K et al. Induction of cyclooxygenase 2 in gastric mucosal lessions and its inhibition by the specific antagonist delays healing in mice. Gastroenterology 1997; 112:387-397.

27. Schmassmann A, Peskar BM, Stettler C, et al. Effects of inhibition of prostaglandin endoperoxide synthase-2 in chronic gastrointestinal ulcer models in rats. $\mathrm{Br} \mathrm{J}$ Pharmacol 1998; 123:795-804.

28. Jones MK, Wang H, Peskar BM, Levin E, Itani RM, Sarfeh IJ, Tarnawski AS. Inhibition of angiogenesis by non steroidal anti-inflammatory drugs:insight into mechanisms and implications for cancer growth and ulcer healing. Nat MNed $1995 ; 5$

29. Wallace JL, McKnight W, Reuter BK, Vergnolle N. NSAID induced gastric damage in rats: requirement for inhibition of both cyclooxygenase 1 and 2 . Gastroenterology 2000; 119:706-14. 